\title{
A NÁTRIUM-JODID MOLEKULA FOTOGERJESZTÉSÉNEK SZABÁLYOZÁSA TERAHERTZES PULZUSOKKAL
}

\author{
Biró Lászlón ${ }^{1}$, Csehi András ${ }^{1}$ \\ ${ }^{1}$ Debreceni Egyetem, Elméleti Fizikai Tanszék, 4026 Debrecen Bem tér 18, Magyarország \\ DOI: https://doi.org/10.14232/kvantumelektronika.9.4
}

\section{Bevezetés}

Intenzív elektromágneses térbe helyezett molekuláris rendszerek belső magdinamikai folyamatainak szabályozása az utóbbi években a tudományos érdeklődés középpontjába került [1-4]. A különböző kontroll sémák közül kiemelt jelentőséggel bír a dinamikus Stark-effektuson alapuló vizsgálati módszer. Ennek lényege, hogy a molekulák potenciális energia felületeinek (PEF) alakja erős lézertérrel módosítható a Stark-eltolódás révén és ezáltal az atommagok mozgása szabályozhatóvá válik. A lézerpulzus paramétereinek megfelelő megválasztásával elérhető a potenciális energia felületek kívánt irányú torzítása ezáltal pedig a magok pályájának alakítása. Íly módon az alkalmazott pulzus időlefolyásának, központi frekvenciájának, intenzitásának, vagy éppen az időkésleltetésének finomhangolásával kontrollálhatóvá válik molekulák fotodisszociációja [2], fotogerjesztése [3], ultragyors időskálán ( $\left.\mathrm{fs}=10^{-15} \mathrm{~s}\right)$ lezajló nemadiabatikus dinamikája [1,2,4]. A femtoszekundumos lézerek megjelenésével széles körben elterjedtek a magok mozgásának leképezésére illetve kontrollálására irányúló elméleti és kísérleti munkák. Lévén, hogy a magok mozgása tipikusan a femto- és pikoszekundumos $\left(10^{-15} \mathrm{~s}-10^{-12} \mathrm{~s}\right)$ időskálán történik, a terahertzes $\left(\mathrm{THz}=10^{12} \mathrm{~Hz}\right)$ tartományba eső lézerpulzusok kiválóan alkalmas eszköznek mutatkoznak molekuláris folyamatok Stark-szabályozására.

Jelen munkában néhány ciklusú terahertzes pulzusok (0.5 THz - 15 THz) alkalmazásával alapállapotú molekulák fotogerjesztésének szabályozási lehetőségeit vizsgáljuk számítógépes szimulációs módszerek segítségével. Meg fogjuk mutatni, hogy a lézer központi frekvenciájának alkalmas megválasztásával a molekulák vibrációs, rotációs, vagy rovibrációs gerjesztése révén a dinamikai viselkedés jelentősen befolyásolható és ezáltal az alkalmazott UV pumpa pulzussal történő fotogerjesztés hatékonysága szabályozható. Numerikus vizsgálati eredményeinket - melyet az időtől függő Schrödinger-egyenlet pontos megoldásával kapunk - a széles körben tanulmányozott nátrium-jodid (NaI) molekula [5,6] példáján mutatjuk be. A NaI molekula rovibrációs hullámfüggvényének analízisén keresztül szemléltetni fogjuk, hogy az alapállapotú rendszer fotogerjesztése széles pumpa energia tartományban módosíthatóvá válik megfelelően megválasztott, a pumpálást megelőző terahertzes kontroll pulzusok alkalmazásával.

\section{Eredmények}

Numerikus vizsgálatunk eredményeit a NaI példáján szemléltetjük kétállapot közelítésben. A lézermolekula kölcsönhatás leírásához az i $\hbar d \psi / d t=H(t) \psi$ időtől függő Schrödenger-egyenletet oldjuk meg a széles körben alkalmazott és nagy pontosságú ún. MCTDH (multi configurational time-dependent Hartree) módszer segítségével [7]. H(t) a lézerrel kölcsönható forgó-rezgő molekula teljes Hamilton-operátora, $\psi(R, \theta, t)$ pedig a megoldás hullámfüggvény mely a rendszerre vonatkozó információt tartalmazza. A terahertzes kontroll és UV pumpa pulzusokkal kölcsönható forgó-rezgő molekula teljes időtől függő Hamilton-operátora dipólközelítésben a következő alakban adható meg az alap- és első gerjesztett elektronállapotok terében [6]:

$$
H(t)=\left[\frac{-1}{2 M} \frac{\partial^{2}}{\partial R^{2}}+\frac{J^{2}}{2 M R^{2}}\right] \cdot \mathbf{1}+\left[\begin{array}{cc}
V_{1} & K \\
-K & V_{2}
\end{array}\right]-E(t) \cdot \cos \theta \cdot\left[\begin{array}{ll}
\mu_{11} & \mu_{12} \\
\mu_{21} & \mu_{22}
\end{array}\right]
$$


ahol $\mathrm{M}$ a redukált tömeg, $\mathrm{R}$ a magtávolság, $\theta$ a molekulatengely és a lézerpolarizációk iránya közötti szög, J² az impulzusmomentum-négyzet operátor, 1 szimbolizálja a 2x2-es egységmátrixot, továbbá a $V_{i}$ potenciálok és a $\mu_{\mathrm{ij}}$ dipólmomentumok $(\mathrm{i}, \mathrm{j}=1,2)$ alakja az 1.ábrán látható. Az (1)-ben megjelenő $K=\frac{1}{2 M}\left[2 f \frac{\partial}{\partial R}+\frac{\partial}{\partial R} f\right]$ nemadiabatikus csatolási operátor az elektronállapotok csatolódását írja le. Az ebben szereplő $f=\left\langle 1\left|\partial_{R}\right| 2\right\rangle$ nemadiabatikus csatolási tag az 1.ábra a) panelén látható. Az (1)-ben szereplő utolsó, fény-anyag kölcsönhatási tagban a lineárisan poláros E(t) elektromos tér a terahertzes kontroll pulzus és az UV pumpa pulzus összegeként áll elő, $E(t)=E_{T H Z} \cdot e^{-t^{2} / 2 \tau_{T H Z}^{2}} \cdot \cos \left(\omega_{T H Z} t\right)+E_{U V} \cdot e^{-(t-\Delta t)^{2} / 2 \tau_{U V}^{2}} \cdot \cos \left(\omega_{U V}(t-\Delta t)\right)$, melyek között $\Delta \mathrm{t} \quad$ az időkésleltetés és a polarizációs irányuk megegyezik. Az itt alkalmazott pulzusok félértékszélessége ( $f w h m=2 \tau \sqrt{\ln 2}$ ) tipikusan az fwhm THZ $_{100}-700$ fs és fwhm 100 fs tartományba esik. A kontroll pulzus intenzitása $I_{T H Z}=10^{12} \mathrm{~W} / \mathrm{cm}^{2}$, míg a pumpa pulzusé $I_{U V}=3 \times 10^{11} \mathrm{~W} / \mathrm{cm}^{2}$ a dolgozat egészében. Fontos megjegyezni, hogy a rendszer kezdő állapota minden esetben a $V_{1}$ potenciál vibrációs és rotációs alapállapota: $v=0, J=0$.
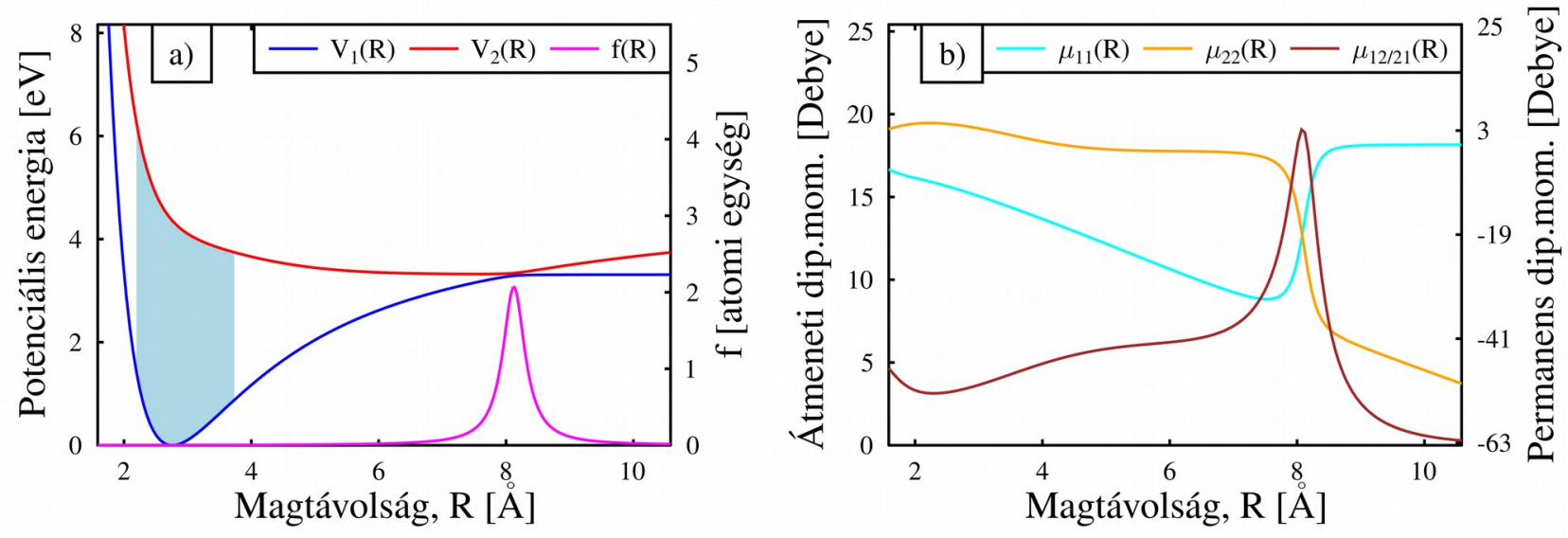

1.ábra (a) A nátrium-jodid molekula alap- és első gerjesztett elektronállapoti potenciális energia görbéi. Az ion- és kovalens állapotok $\mathrm{R} \sim 8$ Å magtávolságnál csatolódnak, amit az energia görbék közelsége valamint az f nemadiabatikus csatolási tag éles maximuma is tükröz (lila görbe). (b) Az elektronállapotok permanens- és átmeneti dipólmomentum görbéi. A dipólmomentumok iránya megegyezik a molekulatengely irányával.

A dolgozatban vizsgált dinamikai folyamat sematikusan a 2.ábrán látható. A pumpa pulzust megelőző néhány ciklusú THz-es pulzus rovibrációsan gerjeszti az alapállapotú molekulát miközben a $\mathrm{V}_{1}(\mathrm{R})$ potenciál görbe dinamikusan oszcillál a Stark-effektus következtében a lézerdipól kölcsönhatási tag időlefolyása szerint: $V_{1}(R, t)=V_{1}(R)-\mu_{11}(R) E_{T H Z} \cdot e^{-t^{2} / 2 \tau_{T H Z}^{2}} \cdot \cos \left(\omega_{T H Z} t\right)$ (lásd a 2.ábra bal oldalán). Ezt követően $\Delta$ t időkésleltetéssel bekapcsoljuk az optikai tartományba eső rövid pumpa pulzust, melynek központi frekvenciáját úgy változtatjuk, hogy az rezonánsan csatolja a $V_{1}$ és $V_{2}$ potenciállal jellemzett alap- és első gerjesztett elektronállapotokat (kék terület az 1.ábrán) a Franck-Condon (FC) tartományban. A fotogerjesztés hatására - a kontroll pulzus paramétereitől függően - a gerjesztett állapot különböző mértékben populálódik $\left(\mathrm{p}_{2}\right)$. Ezt követően a gerjesztett molekula magtávolsága növekedni kezd ( $\mathrm{V}_{2}$ gradiensének megfelelően) majd kb. 200 fs elteltével eléri a nemadiabatikus csatolási tartományt ( $\mathrm{R} \sim 8$ Å) ahol sugárzásmentesen legerjesztődik a rendszer, visszajut az alapállapotba és ott disszociál (kék terület a 2.ábrán). Íly módon közvetetten nem csak a fotogerjesztés, hanem az azt követő disszociáció is szabályozható. 


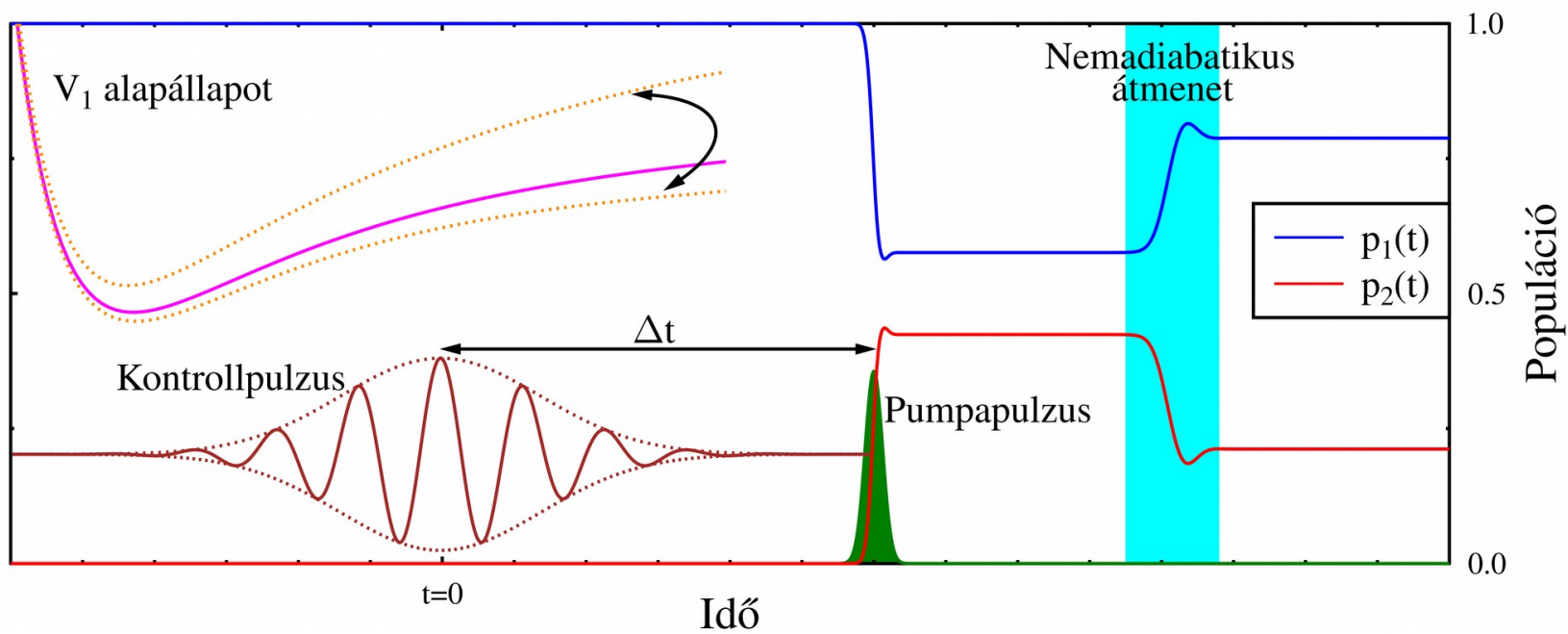

2.ábra A dolgozatban alkalmazott lézer kontroll séma. Az alapállapotú NaI molekulát $\mathrm{THz}$ tartományba eső néhány ciklusú pulzussal megvilágítjuk, ami az alapállapoti potenciál Starkeltolódása révén a molekula vibrációs gerjesztését eredményezi. Az időkésleltetéssel bekapcsolt UV pumpa pulzus az alkalmazott kontroll paramétereitől függően más és más állapotban találja a rendszert, ezáltal pedig eltérő mértékben populálja a gerjesztett állapotot. A gerjesztett molekula kb. 200 fs elteltével eléri a nemadiabatikus csatolási tartományt ahol legerjesztődve visszajut az alapállapotba és ott disszociál Na és I atomokra.

A NaI molekula $\psi_{1}(R, \theta, t)$ alapállapoti hullámfüggvényének időfejlődését jelentős mértékben befolyásolja az alkalmazott kontroll pulzus központi frekvenciája. A frekvenciát változtatva a 0.5 $\mathrm{THz}-15 \mathrm{THz}$ tartományban $\left(17 \mathrm{~cm}^{-1}-500 \mathrm{~cm}^{-1}\right)$ azt tapasztaljuk, hogy kisebb energiákon a molekulának a lézerpolarizáció irányába történő rendeződése zajlik, míg az energia növelésével egyre inkább a vibrációs gerjesztés válik dominánssá (részletekért lásd a [8]-as hivatkozást). Pumpa nélkül, csupán a kontroll pulzust bekapcsolva és változtatva annak $\hbar \omega_{T H z}$ energiáját azt találjuk, hogy az alapállapotú molekula magtávolságának várható értéke $(\langle R\rangle)$ valamint a maghullámcsomag szélességének várható értéke $(\langle\Delta R\rangle)$ éles maximumot mutat a $\hbar \omega_{T H z}=121 \mathrm{~cm}^{-1}$ és a $\hbar \omega_{T H Z}=242 \mathrm{~cm}^{-1}$ értékeknél [8]. Ezen energia értékek megfelelnek az alapállapotú NaI molekula $v=0 \quad$ és $\quad v=1$ vibrációs állapotai közti két- és egyfotonos átmeneteknek.

Most vizsgáljuk meg konkrétan a $\psi_{1}(R, \theta, t)$ alapállapoti maghullámfüggvény időfejlődését néhány karakterisztikus kontroll energia esetén. A kapott eredményeket a 3.ábra mutatja a $\hbar \omega_{T H z}=102 \mathrm{~cm}^{-1}$ $\hbar \omega_{T H Z}=242 \mathrm{~cm}^{-1}$ és $\hbar \omega_{T H Z}=500 \mathrm{~cm}^{-1}$ kontroll energiákra. A baloldali panelek a vibrációs, míg a jobboldali panelek a rotációs dinamikát szemléltetik. A kontúrok színkódja a panelek jobb szélén azt mutatja, hogy milyen nagy a vibrációs illetve rotációs hullámfüggvényből számolt megtalálási valószínűség sűrűség értéke az $\mathrm{R}$ illetve $\theta$ koordináták mentén az idő függvényében. Mindegyik panelen feltüntettük a terahertzes kontroll pulzus alakját (kék görbe). A vibrációs esetben a maghullámfüggvény szélességének várható értékét narancs vonal jelöli (jobboldali y tengely), míg a rotációs esetben a forgási kvantumszám legvalószínübb értékének időfejlődését lila görbe mutatja (jobboldali y tengely). A 3.ábra(a) tanúsága szerint $102 \mathrm{~cm}^{-1}$ energián csekély mértékű vibrációs gerjesztés történik: a maghullámfüggvény pozíciója és szélessége kis mértékben megváltozik a pulzus ideje alatt, azonban a pulzus után ezen mennyiségek visszaállnak eredeti értékükre. Ezzel szemben jelentős rotációs dinamika zajlik ezen az energián (3.ábra(b)): a kezdetben izotróp 
eloszlású rendszer ( $\mathrm{J}=0$ ) a pulzus hatására erősen anizotróppá válik, a lineáris molekula rendeződik a kontroll pulzus polarizációjának irányába (lásd az éles piros csúcsokat $\theta=0$ és $\theta=\Pi$ körül). A forgási gerjesztettséget jól tükrözi a J kvantumszám legvalószínűbb értékének növekedése (lila görbe), valamint annak pulzus utáni megmaradó értéke ( $\mathrm{J}=16)$.
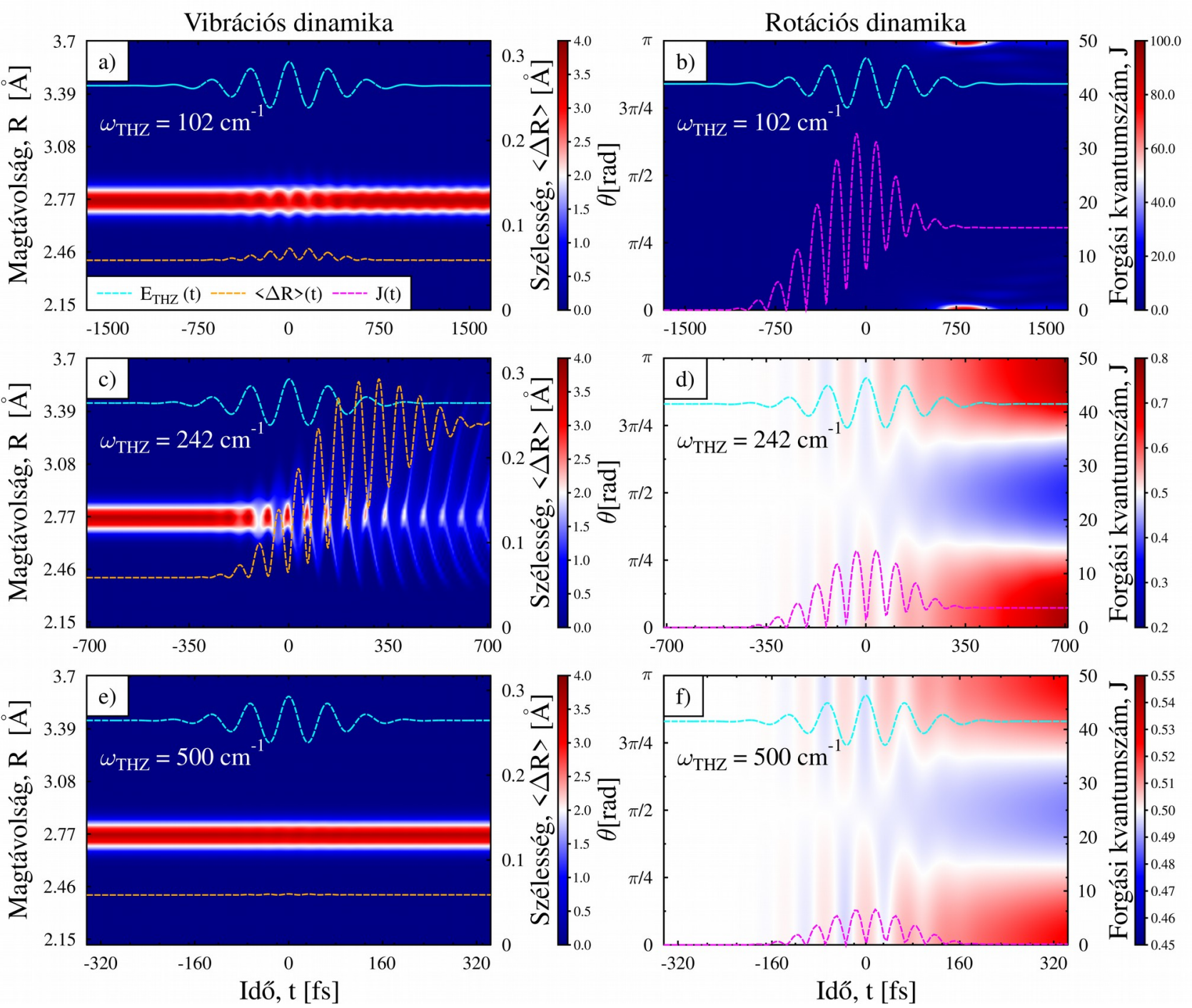

3.ábra A NaI molekula vibrációs (baloldali panelek) és rotációs (jobboldali panelek) hullámcsomag dinamikája a $\mathrm{V}_{1}$ alapállapoti potenciálon. Az alkalmazott kontroll pulzus központi frekvenciájának megfelelő megválasztásával a magdinamika különböző tartományait tanulmányozhatjuk. Alacsony energiákon a molekula irányítását ( $\hbar \omega_{T H Z}=102 \mathrm{~cm}^{-1}$ ), míg közepes energiákon annak vibrációs gerjesztését indukálhatjuk ( $\hbar \omega_{T H Z}=242 \mathrm{~cm}^{-1}$ ). Az energia további növelésével a vibrációs és rotációs gerjesztés egyaránt elhanyagolhatók $\left(\hbar \omega_{T H Z}=500 \mathrm{~cm}^{-1}\right)$. A molekula kezdeti állapota minden esetben a vibrációs és rotációs alapállapot $(v=0, J=0)$.

$\hbar \omega_{T H Z}=242 \mathrm{~cm}^{-1}$ energián - mely megfelel a molekula $v=0 \rightarrow v=1$ vibrációs átmenetének $-\mathrm{a}$ kontroll pulzus jelentős rezgési gerjesztést indukál (3.ábra(c)). Amint a pulzus eléri a maximumát, a a vibrációs hullámcsomag szélessége periodikusan oszcillálni kezd az $\mathrm{R}_{0}=2.77 \AA$ egyensúlyi magtávolság körül. A hullámcsomag szélességének várható értéke $(\langle\Delta R\rangle)$ a pulzus leszálló ágában mintegy háromszorosára növekszik a kiinduló értéknek (narancs görbe a 3.ábra(c)-n). Mindeközben nem elhanyagolható a rendszer forgása (3.ábra(d)): a kezdeti izotróp eloszlás megszúnik és most is 
$\theta=0$ és $\theta=\Pi$ köré rendeződnek a molekulák, de korántsem olyan nagy mértékben mint kisebb energián; továbbá a pulzus utáni J érték is jelentősen kisebb (J=3) mint korábban.

Tovább növelve a kontroll pulzus energiáját $\left(\hbar \omega_{T H Z}=500 \mathrm{~cm}^{-1}\right)$ sem vibrációs, sem jelentékeny rotációs gerjesztés nem történik (3.ábra(e)-(f)): az $\langle R\rangle$ és a $\langle\Delta R\rangle$ értéke nem változik a pulzus ideje alatt, továbbá az izotróp eloszlás jó közelítéssel megmarad és $J=0$ értéket kapunk a pulzus után. Ilyen nagy energiák - nagy frekvencia, kis periódusidő - esetén a potenciál dinamikus Starkeltolódása olyan gyorsan történik, hogy a molekula ezt már nem tudja követni és így a kontroll pulzus gerjesztő hatása nem érvényesül.

\section{3. Összegzés és konklúziók}

A 3.ábrán bemutatott rotációs-vibrációs hullámcsomag időfejlődésének analízise alapján láthattuk, hogy mely kontroll energiák eredményeznek elsősorban forgási, melyek pedig főként rezgési gerjesztést a NaI molekula esetében. Ezek alapján azt várjuk, hogy a különböző energia tartományokban a molekula fotogerjesztésének hatékonysága meg fog változni lévén, hogy a hullámcsomag eloszlása is megváltozott az $\{\mathrm{R}, \theta\}$ térben a kontroll pulzus hatására.
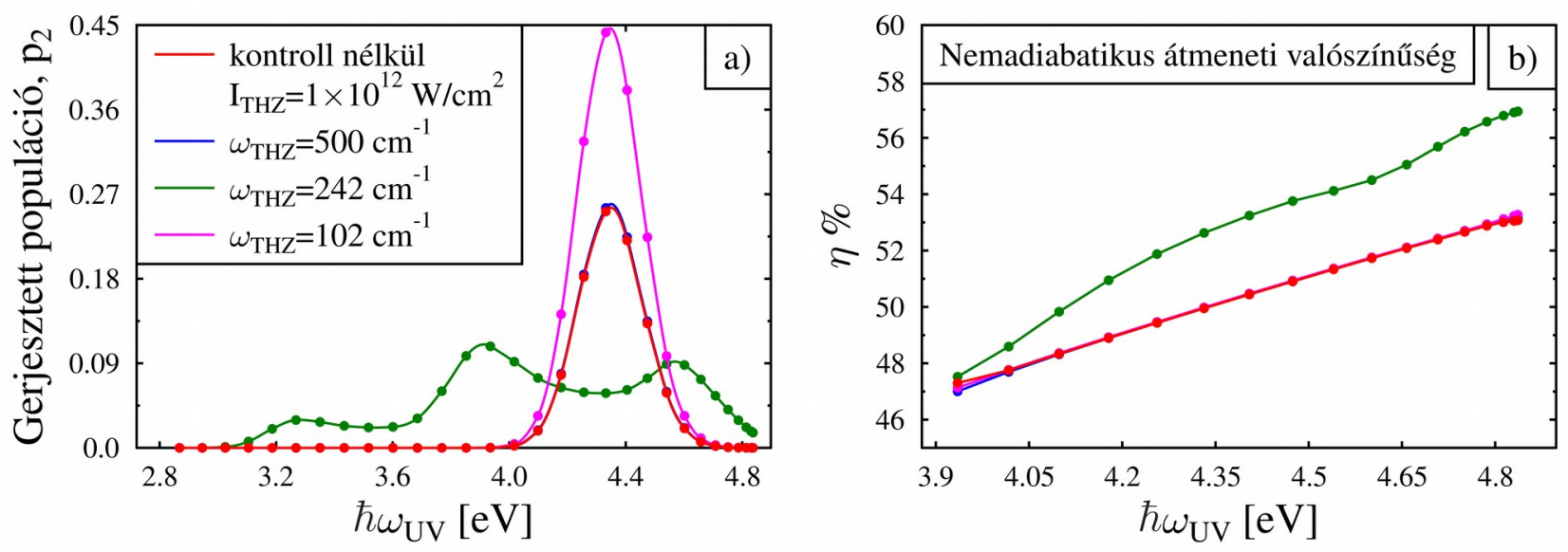

4.ábra (a) Alapállapotú NaI molekula gerjesztési profilja kontroll pulzus nélkül (piros görbe) és különböző központi frekvenciájú kontroll pulzusok esetén: $\hbar \omega_{T H Z}=242 \mathrm{~cm}^{-1}$ esetén az alapállapoti hullámcsomag szétterül, ezáltal széles energia tartományban gerjeszthetővé válik a rendszer, míg $\hbar \omega_{T H Z}=102 \mathrm{~cm}^{-1}$ esetén a molekulának a lézerpolarizáció irányába állása révén jelentősen megnövelhető a pumpálás hatékonysága. (b) A pumpálást követő nemadiabatikus legerjesztődés valószínűsége. Növekvő pumpa energiával illetve vibrációs gerjesztettség esetén (zöld görbe) megnövekszik a nemadiabatikus átmenet hatékonysága.

Ennek ellenőrzése érdekében számoljuk ki a molekula gerjesztési profilját a kontroll pulzus alkalmazása után, azaz pásztázzunk az UV pumpa pulzus energiájával a $V_{1} \leftrightarrow V_{2}$ rezonancia környezetében (kék terület az 1.ábrán) és számoljuk ki a gerjesztett állapot $\mathrm{p}_{2}$ betöltöttségét a pumpálás után. A kapott eredmények a 4.ábra a) panelén láthatók különböző kontroll energiák esetén. A kontroll nélküli esetet a piros görbe mutatja, ami alapján látható, hogy az alap- és első gerjesztett elektronállapotok között a legvalószínúbb átmenetet $\hbar \omega_{U V}=4.35 \mathrm{eV}$ pumpa energia esetén kapjuk. $102 \mathrm{~cm}^{-1}$-es kontroll energián a gerjesztés valószínűsége jelentős mértékben megnövekszik (lila görbe), azonban a gerjesztési profil alakja változatlan marad (továbbra is 4.35 
eV pumpa energián maximális a gerjesztés hatékonysága). Ennek oka, hogy a tér irányába történő rendeződés révén a molekula által a pumpálás során érzékelt effektív térerősség nagy mértékben megnövekedett.

Ezzel ellentétben $242 \mathrm{~cm}^{-1}$-es kontroll energián a gerjesztési profil alakja számottevően megváltozik és a gerjesztés hatékonysága széles pumpa energia tartományban szabályozhatóvá válik (zöld görbe). Mindez azzal magyarázható, hogy a $V_{1}$ Stark-eltolódása révén a maghullámfüggvény kiszélesedik, ezáltal pedig kis és nagy magtávolságoknál egyaránt gerjeszthetővé válik a molekula. A zöld görbe alakja íly módon közvetetten tükrözi az alapállapoti hullámcsomag alakját a pumpálás pillanatában. Tovább növelve a kontroll pulzus energiáját $\left(500 \mathrm{~cm}^{-1}\right)$ nem történik jelentős változás a kiinduló hullámcsomagban, így a gerjesztési profil sem módosul jelentős mértékben (kék görbe). Végezetül megjegyezzük, hogy a fotogerjesztést követően kb. 200 fs elteltével a molekula nemadiabatikus legerjesztődés révén visszakerül alapállapotba és ott disszociál Na és I atomokra. A legerjesztődés valószínűsége annál nagyobb, minél több energiát vittünk a rendszerbe, azaz a pumpa energia növelésével növekszik (4.ábra(b)) továbbá vibrációs gerjesztettség esetén is számottevően megemelkedik.

\section{Köszönetnyilvánítás}

A kutatást az EFOP-3.6.2-16-2017-00005 azonosítójú, EU társfinanszírozású projekt támogatta.

\section{Irodalom}

[1] B.J. Sussman, D. Townsend, M.Y. Ivanov, A. Stolow, Science 314, 278 (2006) https://doi.org/10.1126/science.1132289

[2] A. Tóth, A. Csehi, G.J. Halász, Á. Vibók, Phys. Rev. Res. 2, 013338 (2020) https://doi.org/10.1103/PhysRevResearch.2.013338

[3] B. Mignolet, B. F. E. Curchod, F. Remacle, T. J. Martínez, J. Phys. Chem. Lett. 10, 742 (2019) https://doi.org/10.1021/acs.jpclett.8b03814

[4] S. Scheit, Y. Arasaki, K. Takatsuka, J. Phys. Chem. A 116, 2644 (2012) https://doi.org/10.1021/jp2071919

[5] T.S. Rose, M.J. Rosker, A.H. Zewail, J. Chem. Phys. 91, 7415 (1989) https://doi.org/10.1063/1.457266

[6] A. Csehi, G.J. Halász, L.S. Cederbaum, Á. Vibók, J. Phys. Chem. Lett. 8, 1624 (2017) https://doi.org/10.1021/acs.jpclett.7b00413

[7] H.-D. Meyer, U. Manthe, L.S. Cederbaum, Chem. Phys. Lett. 165, 73 (1990) https://doi.org/10.1016/0009-2614(90)87014-I

[8] Biró L., MSc Diplomamunka, Debreceni Egyetem (2020) 